\title{
A Review on Role of Peptide Vaccines in Cancer Therapy Treatment of Cancer Disease by Peptide Vaccine
}

\author{
Timothy Allen ${ }^{1}$, Ghazaleh Shoja E Razavi MD ${ }^{2, *}$, Giridhar M.N.V \\ ${ }^{1}$ Global Allied Pharmaceutical, Center for Excellence in Research \& Development, USA \\ ${ }^{2}$ Dir. Clinical Development- Oncology and Respiratory, Global Allied Pharmaceutical, USA \\ ${ }^{3}$ Global Allied Pharmaceutical, USA
}

Copyright (C) 2014 Horizon Research Publishing All rights reserved.

\begin{abstract}
The article discuss about the role of peptide vaccine in Cancer therapy. A peptide vaccine is a type of vaccine in which a peptide of the original pathogen is used to immunize an organism.
\end{abstract}

Keywords Vaccines, Angiogenesis, Monoclonal Antibodies (mAbs), TAA Peptides, Cytotoxic T lymphocyte (CTL) CD8+ T-cells, Killer T cell, Cancer Vaccine

\section{Introduction}

There has been a lot of development in the field of peptide vaccines and several clinical trials have also been carried out since the first peptide-base vaccine clinical trial on melanoma antigen in 1995. Earlier, the peptide vaccines were restricted to the single antigen of human leukocyte. Vast development has been taking place, at present in the field of peptide vaccines. ${ }^{[5] .}$

\section{History of Peptide Vaccine}

The concept of activating the immune system of patient against the cancer has been proposed long ego.. William Coley was the first person to start a trial on immunotherapy for the treatment of cancer in 1890-91. On the basis of observations of the patients diagnosed with erysipelas and subsequent reduction in tumor growth, Coley injected a strain of live Streptococcus pyogenes into the tumor of the patient. He postulated that the body would fight against the infection and destroy the tumor by the process of "collateral damage". The patients developed fever, chills and headache along with bacterial sepsis. However, there was also a reduction in the size of the tumor due to hemorrhagic necrosis ${ }^{[6]}$ The experiment resulted in a number of deaths due to sepsis. . Coley modified the research of the vaccination by using the filtrates that were free of bacterial cells and that too in a combination-culture of Streptococcus and Serratia marcescens. ${ }^{[7]}$ However, the introduction of chemotherapy and radiation therapy put Coley's work to the back seat.
Then, in 1970's, Bacillus Calmette-Guerin (BCG) was developed as a treatment option for bladder cancer in earlier stages. It also got an approval in 1990 from Food and Drug Administration (FDA) as a first-line therapy for superficial bladder cancer and is being used till now. However, BCG could not prove its efficacy against lung cancer. Nowadays, the research on cancer vaccines concentrates on target based therapy on the tumor-associated antigens (TAA). ${ }^{[8]}$

Sipuleucel-T, under the brand name Provenge ${ }^{\circledR}$ was the first vaccine approved by U.S. FDA for therapeutic purposes against prostate cancer. ${ }^{[9]}$ It consists of Antigen Presenting Cells (APC's) obtained by the process of leukapheresis from the mononuclear cells of the patient's blood.

\section{Cancer Vaccines and Cell Immunotherapy}

] A cancer vaccine involves the administration of antigens, an agent which is typical of a cancer along with the immune function boosting factors. This augments the immune system of the patient and helps in attacking and eliminating the cancerous cells ${ }^{[10]}$

Different types of vaccines for cancer are as mentioned below;

1. Tumor Antigen-Based Cancer Vaccines

- $\quad$ DNA Vaccine

- $\quad$ Peptide Vaccine

2. Monoclonal Antibodies

3. Cell-Based Immunotherapy

Cancer vaccines have an edge over other cancer therapies as they develop an immune-response and are site-specific. [11] Thrapeutic Peptide Vaccines has wide applications due to ease of production, site specificity, safety parameters and good results in preclinical studies and. ${ }^{[12] .}$ In today's clinical world, the discovery of antigens that are associated with tumor or specific to the tumor has led to the development of different approaches that cover vaccines of the cancer and immunotherapy.. Immunotherapeutic approaches to cancer are broadly divided into two main categories -Passive and Active Therapies ${ }^{[13]}$ 


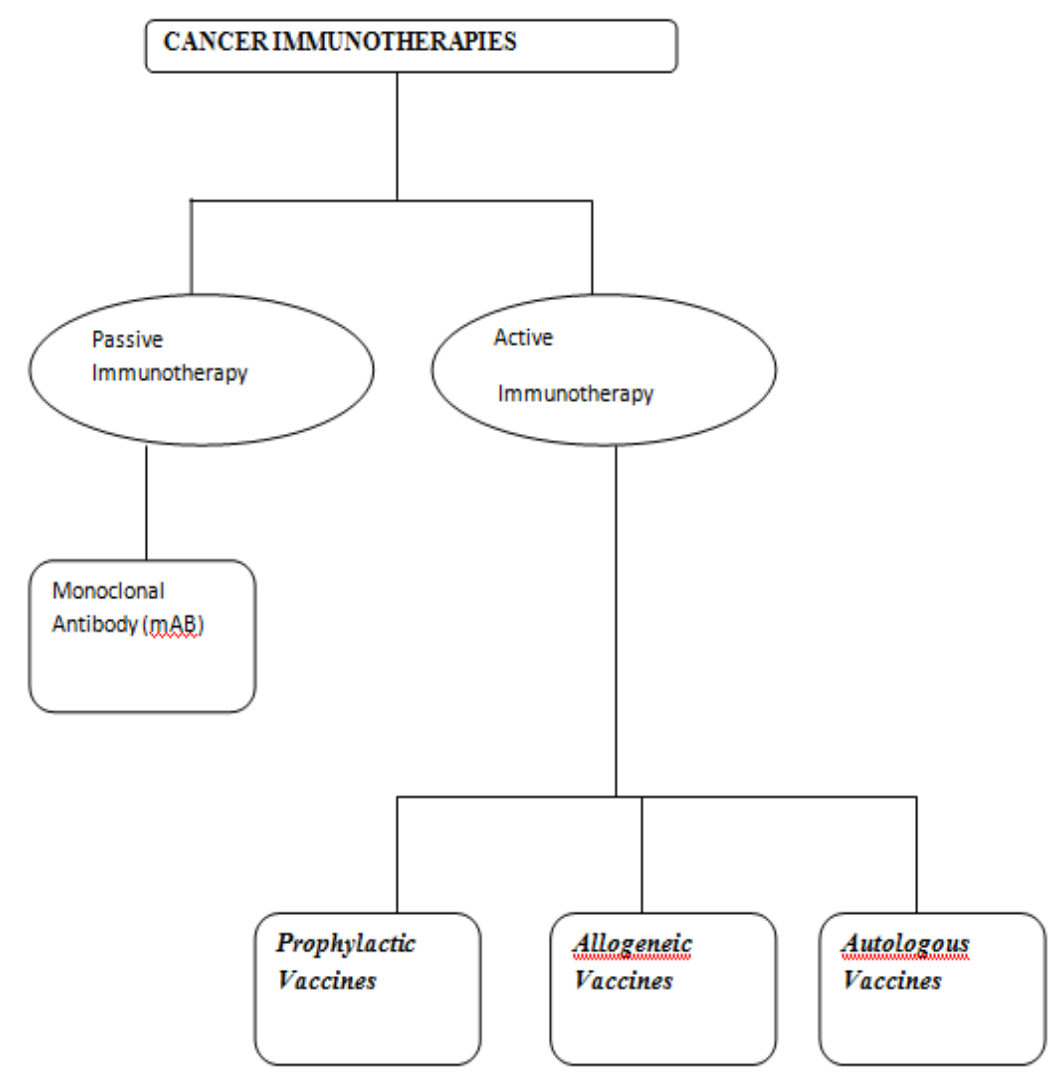

Figure 1. A flow chart represents cancer immunotherapy categories[13]

\section{Passive Immunotherapy}

Passive immunotherapy may be defined as the mode of treatment where an external therapeutic substance is introduced in the patient directly at the site of action.. One of the most leading and successful example of this category is monoclonal antibodies (mAbs). The mAbs were discovered in the 1970s and are also known as "magic bullets" [14]

- Non-Specific Passive Immunotherapy: Use of cytokines and other signaling pathways to generate an immune system, which is non-specific in nature.

- Specific Passive Immunotherapy: In this type of immunotherapy, the immune responses are mediated against specific antigens, which might be either cell-mediated or antibody mediated [15]

\section{Monoclonal Antibodies}

Monoclonal antibodies are one of the effective in the treatment of numerous human malignancies. They are developed through cell which produce single antibody and identify a single antigen. ${ }^{[16]}$

\section{Anti-IdioType antibodies}

Antibody directed against an individual structural antigenic determinant at or close to idiotopes. Idiotopes means antibody combining sites. It recognizes the antigenic determinant that are overlapped a portion of combining site including original antigen in vicinity. When administered, antibodies bind to tumor antigen site and identify antibodies by creating network and amplification of immune response.

\section{Active Immunotherapies}

Active immunotherapies will stimulate immune response by introduction of antigen. They can further be classified down into three categories:

- Prophylactic Vaccines: these types of vaccine are generated and induce in patient prior to progression of disease. These antigens circulate in the body system and when there is cancer cell detected, antibodies are generated for the prevention.

- Allogeneic Vaccines: these are developed by off-the-shell vaccine using cells of allogeneic tumor. They are bespoken vaccine. Examples Of Allogeneic Vaccine-Apthera: NeuVaxBristol-Myers: MDX-1379Cel-Sci:MultikineCellDex/Pfizer:

CDX-110Generex Biotech: AE37GlaxoSmithKline: MAGE-3Immatics: IMA901 /IMA910Immutep: IMP321Oncothyreon: Stimuvax

- Autologous Vaccines: in this vaccine, antigen are derived from patient itself and induce regression of synergic tumors. Examples Of Autologous Vaccine-Antigenics: OncophageBioVest Int'l: BioVaxIDGenitope Corp: MyVax

Both Allogeneic and Autologous vaccines are active once the cancer is detected and diagnosed. Irradiated whole cells or cell lysates are used for the preparation and for treatment purpose. ${ }^{[18]}$ 


\section{Overview of Peptide Vaccine}

Amino acid sequences (peptide) are the building block for peptide vaccine. Antigen stimulates the immune response by recognizing the tumor cell. Epitope based peptide vaccines are upgraded and effective in the treatment of tumor in comparison to conventional whole organism based vaccines. [19] They generate adaptive immune response by introduction of tumor-associated antigens directly to patient. The response can be either allogeneic or autologous. Antigen can express themselves at tumor specific site or at different tumor types with tumor-specific post-translational modified proteins.[20]

Carrier system such as bacterial cells, lipid mixtures, or virus particles are one of the novel drug delivery system introduced for peptide vaccine. A mutation of human epidermal growth factor receptor (EGFR) known as EGFRvIII is highly expressed in case of giolma cancer. [21]

Peptide vaccine is now effectively in use for the treatment of various ailments, like cancer, diabetes, and cardiovascular diseases. Chemotherapy leads to systemic toxicity and adversely affects adjuvant normal cells. Molecularly targeted cancer therapies are the solution for that with improved drug potency and efficiency.

Peptides have shorter half-life in vivo. To overcome this hurdle, novel drug delivery system is introduced with modification in peptide sequences. They are used via carriers like cytotoxic drug and radio-nuclide carriers or by targeting drug to tumor site directly.

Various GMP tools are maintaining the standards for the purity and identity of the peptides. Analytical tools like high-performance like liquid chromatography (HPLC) and mass spectrometry (LC-MS) analysis are continuously updating the current knowledge. [28]

Leukemia cells can act as antigen-presenting cells (APCs) that degrade endogenous leukemia antigens in their proteasome and express on the HLA class I and II pathway. CD4 helper and CD8 cytotoxic T lymphocytes (CTLs) are the stimulation reaction for LAA-derived peptides.

\section{Current Status of Peptide Based Anti-cancer Agents}

Peptide based anti-cancer agent are still under development phase. It works at microenvironment level due to difference in the physioloiy. Cell targeting is the most advanced and exploited area. In spite of peptide can be used for multicomponent gene delivery complexes for cell-specific targeting.[29] The Advantage and disadvantage of peptide vaccine are as mentioned in table 2:-[30]

Initially, single HLA type was developed but now several epitopes based peptides are under investigation. [31] Multivalent long peptide vaccines; multi-peptide vaccines consisting of CTL- and helper-epitopes; peptide cocktail vaccines; hybrid peptide vaccines; personalized peptide vaccines; and peptide-pulsed dendrites cell vaccines are the subheading under which vaccine development going on. Various studies have published their results under these subheadings as well.

\section{Conclusions}

Cancer vaccine and immunotherapy is a complex and challenging process. A peptide vaccine provides several advantages in comparison to conventional vaccines. Vaccines of peptide are a safe and economical technology compared to traditional vaccines made of dead or attenuated pathogens, inactivated toxins, and recombinant subunits. . Peptide Vaccines avoid the inclusion of unnecessary components possessing high react to immune response to the host, such as lipopolysaccharides, lipids, and toxins., peptide vaccines can be composed of various epitopes from different antigens, and integrate $\mathrm{T}$ cells and $\mathrm{B}$ cells epitopes into one antigenic formulation. The future peptide vaccine delivery strategies may target the combination of adjuvant in formulations, strategies to enhance the ability to enhance antigen uptake, novel adjuvant to stimulate innate immunity and induce specific adaptive immune response.

Table 1. an update on vaccine trials

\begin{tabular}{|c|c|c|c|c|}
\hline Vaccine & Phase & Indication & CT identifier & Reference \\
\hline $\begin{array}{l}\text { Peptide Vaccine (LPV7) + Tetanus } \\
\text { peptide }\end{array}$ & $\mathrm{I} / \mathrm{II}$ & $\begin{array}{c}\text { Melanoma } \\
\text { Metastatic Melanoma } \\
\text { Mucosal Melanoma }\end{array}$ & NCT02126579 & 22 \\
\hline $\begin{array}{l}\text { Autologous Ad HER2 dendritic cell } \\
\text { vaccine }\end{array}$ & I & $\begin{array}{c}\text { Breast Neoplasms } \\
\text { Breast Cancer } \\
\text { Adenocarcinomas } \\
\text { Metastatic Solid Tumors Characterized by } \\
\text { HER2/Neu Expression }\end{array}$ & NCT01730118 & 23 \\
\hline $\begin{array}{c}\text { Two Folate Binding Protein (FBP) } \\
\text { Peptide Vaccines (E39 and J65) }\end{array}$ & $\mathrm{I} / \mathrm{II}$ & $\begin{array}{l}\text { Breast Cancer } \\
\text { Ovarian Cancer }\end{array}$ & NCT02019524 & 24 \\
\hline MAGE-3 & III & $\begin{array}{c}\text { Completely resected, } \\
\text { stage IB, II or IIIA NSCLC }\end{array}$ & NCT00290355 & 25 \\
\hline Lucanix & II & $\begin{array}{c}\text { Stage IIIA (T3N2 only), IIIB or IV } \\
\text { NSCLC }\end{array}$ & NCT01058785 & 26 \\
\hline Stimuvax & II & $\begin{array}{l}\text { Un resectable stage III } \\
\text { NSCLC }\end{array}$ & NCT01058785 & 27 \\
\hline
\end{tabular}


Table 2. Advantage And Disadvantage Of Peptide Vaccine ${ }^{[30]}$

\begin{tabular}{|c|c|c|}
\hline Category & Advantage & Disadvantage \\
\hline \multirow[t]{4}{*}{ Peptide } & $\begin{array}{l}\text { direct monitoring of } \mathrm{T} \text { cell responses induced by the vaccine } \\
\qquad \text { possible } \\
\text { epitopes introduction can avoids use of uncharacterized } \\
\text { antigens that may have nontherapeutic autoimmune activity }\end{array}$ & $\begin{array}{c}\text { Class I MHC restriction limits relevance of } \\
\text { individual peptides to certain HLA types } \\
\text { Short peptides may bind directly to MHC on } \\
\text { non-professional APC }{ }^{*} \text {, which may induce } \\
\text { tolerance }\end{array}$ \\
\hline & Strong CD8+ T cell response & HLA-restriction \\
\hline & Allow specific monitoring of the patient's immune response & Degradation in absence of adjuvant \\
\hline & Repeated booster vaccines feasible & $\begin{array}{l}\text { Immune responses may be transient and/or } \\
\text { of low magnitude }\end{array}$ \\
\hline $\begin{array}{l}\text { Anti-idiotypic } \\
\text { antibodies }\end{array}$ & $\begin{array}{l}\text { Unrestricted HLA population and Elicit both humoral and } \\
\text { cellular immune response }\end{array}$ & Human anti-mouse antibody response \\
\hline
\end{tabular}

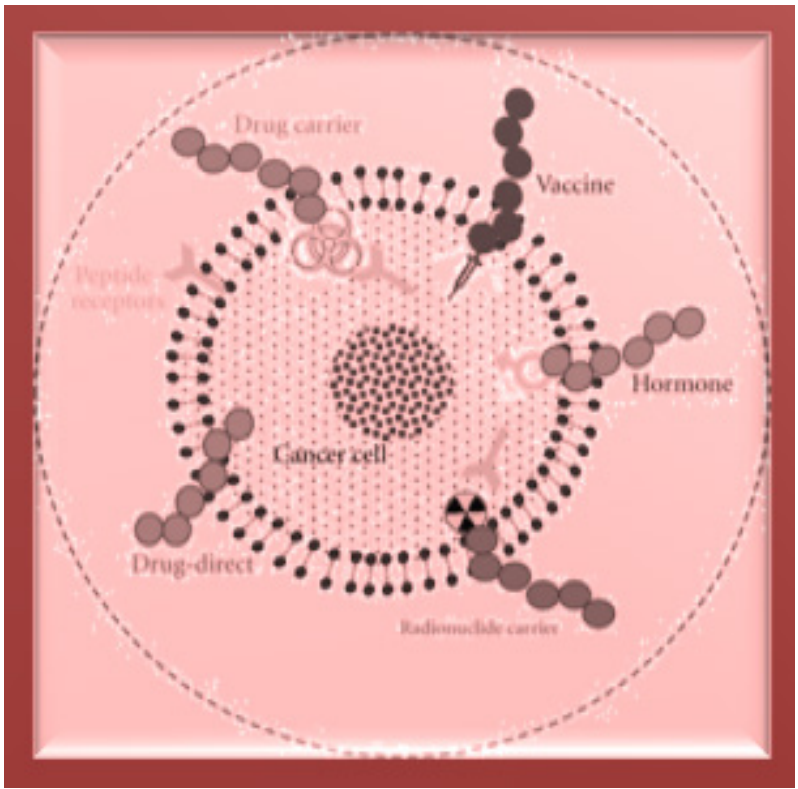

Figure 2. Peptide and possible cancer treatment approaches

\section{Abbreviations}

mABs -Monoclonal antibodies (mAbs)TAATumor-associated antigens, LHRH- Luteinizing Hormone-Releasing Hormone FSH - Follicle-Stimulating hormone TCR - T- cell receptor, Bacillus Calmette-Guerin BCG, Food and Drug Administration (FDA)

\section{REFERENCES}

[1] National cancer institute what is cancer[Online]Available from: http://www.cancer.gov/cancertopics/cancer library/what-is-cancer [Accessed: 19th august2014]

[2] World Cancer Report 2014, available on http://www.who.int/mediacentre/factsheets/fs297/en/, last updated on November 2014, accessed on [10DEC2014]

[3] "Global cancer facts \& figures," 2nd edition, American Cancer Society, available on http://www.cancer.org/research/cancerfactsstatistics/cancerfa ctsfigures2014/, accessed on [10DEC2014]
[4] "Global cancer facts \& figures," 2nd edition, American Cancer Society, available on

http://www.cancer.org/acs/groups/content/@research/docum ents/document/acspc-041776.pdf, accessed on [10DEC2014]

[5] Sridhar Rao PN, Vaccine; Ritz, J. et al. Blood. 59:1-11 (1982). available on site [http://www.microrao.com/micronotes/vacc ines.pdf] last updated on June 2006; [ accessed on 12DEC2014]

[6] Coley WB. II. Contribution to the Knowledge of Sarcoma. Ann Surg. 1891Sep;14(3):199-220

[7] C Hoption, J P van Netten, and C van Netten, Dr William Coley and tumour regression: a place in history or in the future Postgrad Med J. Dec 2003; 79(938): 672-680

[8] RA, Mahler DA, Beck GJ, et al. Intratumoral Bacillus Calmette-Guérin immunotherapy prior to surgery for carcinoma of the lung: results of a prospective randomized trial. Cancer Res 1986;46:5963-8

[9] O. H. Aina, T. C. Sroka, M. L. Chen, and K. S. Lam, "Therapeutic cancer targeting peptides," Biopolymers, vol. 66, no. 3, pp. 184-199, 2002

[10] Nicholas P. Restifo, Countering the 'counterattack' hypothesis, Nat Med. Mar 2001; 7(3): 259

[11] Hoos A, Parmiani G, Hege K, Sznol M, Loibner H, EggermontA,Urba W, Blumenstein B, Sacks N, Keilholz U, Nichol G (2007)Cancer vaccine clinical trial working group $A$ clinical development paradigm for cancer vaccines and related biologics.Immunotherapy30:1

[12] Perez SA, von Hofe E, Kallinteris NL, Gritzapis AD, Peoples GE, Papamichail M, Baxevanis.,2010

[13] Michael D. Becker, Janet Dally, and Jeffrey Martini, (MD Becker Partners LLC) Cancer Vaccine Therapies: Failures and Future Opportunities, 2010

[14] Rüttinger, D. etal.,(2010)

[15] Veltman JD, Lambers ME, van Nimwegen M, de Jong S, Hendriks RW, Hoogsteden HC, Aerts JG, Hegmans JP., Low-dose cyclophosphamide synergizes with dendritic cell-based immunotherapy in antitumor activity, J Biomed Biotechnol. 2010;2010:798467

[16] Finn O.J., "Cancer Vaccines: Between the Idea and the Reality" Nature Reviews Immunol (2003) 3:630-641

[17] Bhattacharya-Chatterjee M1, Chatterjee SK, Foon KA., Anti-idiotype antibody vaccine therapy for cancer, Expert OpinBiolTher. 2002 Dec;2(8):869-81 
[18] Copier J, Dalgleish A, Overview of tumor cell-based vaccines. Int Rev Immunol, (2006) 25: 297-319

[19] Wang CY, Walfield AM. Site-specific peptide vaccines for immunotherapy and immunization against chronic diseases, and for veterinary applications. Vaccine 2005, 23:2049-2056

[20] Li, G. et al. NeurosurgClin N Am. 21(1): $87-93$ (2010)

[21] Gaugler, B. et al. J Exp Med. 179(3): 921-30 (1994)

[22] University of Virginia, Craig L Slingluff, Jr, University of Virginia Phase I/II Trial of a Long Peptide Vaccine (LPV7) Plus TLR Agonists (MEL60): ClinicalTrials.gov [Internet]. Bethesda (MD): National Library of Medicine (US). 2000[2014DEC12]. Available from: https://clinicaltrials.gov/ct2/show/NCT02126579 NLM Identifier: NCT02126579

[23] National Cancer Institute (NCI), National Institutes of Health Clinical Center (CC) ( National Cancer Institute (NCI) ). Ad/HER2/Neu Dendritic Cell Cancer Vaccine Testing: ClinicalTrials.gov [Internet]. Bethesda (MD): National Library of Medicine (US). 2000- [2014DEC12]. Available from:

https://clinicaltrials.gov/ct2/show/NCT01730118?term=NCT 01730118\&rank=1 NLM Identifier: NCT01730118

[24] COL George Peoples, MD, FACS, COL George Peoples, MD, FACS, San Antonio Military Medical Center. Phase Ib Trial of Two Folate Binding Protein Peptide Vaccines (E39 and J65) in Breast and Ovarian Cancer Patients: ClinicalTrials.gov [Internet]. Bethesda (MD): National Library of Medicine (US). 2000- [2014DEC12]. Available from: https://clinicaltrials.gov/ct2/show/NCT02019524?term=NCT 02019524\&rank=1 NLM Identifier: NCT02019524
[25] Vansteenkiste J, Zielinski M, Linder A, Dahabreh J, Gonzalez EE, Malinowski W, Lopez-Brea M, Vanakesa T, Jassem J, Kalofonos H, Perdeus J, Bonnet R, Basko J, Janilionis R, Passlick B, Treasure T, Gillet M, Lehmann FF, Brichard VG. Adjuvant MAGE-A3 immunotherapy in resected non-small-cell lung cancer: phase II randomized study results. J Clin Oncol. 2013 Jul 1;31(19):2396-403

[26] Fakhrai H, Mantil JC, Liu L, Nicholson GL, Murphy-Satter CS, Ruppert J, Shawler DL. Phase I clinical trial of a TGF-beta antisense-modified tumor cell vaccine in patients with advanced glioma. Cancer Gene Ther. 2006 Dec;13(12):1052-60

[27] Nemunaitis J, Dillman RO, Schwarzenberger PO, Senzer N, Cunningham C, Cutler J, Tong A, Kumar P, Pappen B, Hamilton C, DeVol E, Maples PB, Liu L, Chamberlin T, Shawler DL, Fakhrai H. Phase II study of belagenpumatucel-L, a transforming growth factor beta-2 antisense gene-modified allogeneic tumor cell vaccine in non-small-cell lung cancer. J Clin Oncol. 2006 Oct 10;24(29):4721-30

[28] Elena VR, Jacob EK, Corban GR, Niranjan BP, Amir PT, Aleksander SP. Anti-angiogenic peptides for cancer therapeutics. Curr Pharm Biotechnol. 2011

[29] Corina B, Christian K, Bernd G. Current strategies for the development of peptide-based anticancer therapeutics. J Peptide Sci. 2005;11(11):713-726.

[30] Berzofsky, JA. et al. J Clin Invest. 113(11): 1515-25 (2004)

[31] C. Palena, S. I. Abrams, J. Schlom, and J. W. Hodge, "Cancer vaccines: preclinical studies and novel strategies," Advances in Cancer Research, vol. 95, pp. 115-145, 2006 